\title{
Groundwater stable isotope profile of the Etosha National Park, Namibia
}

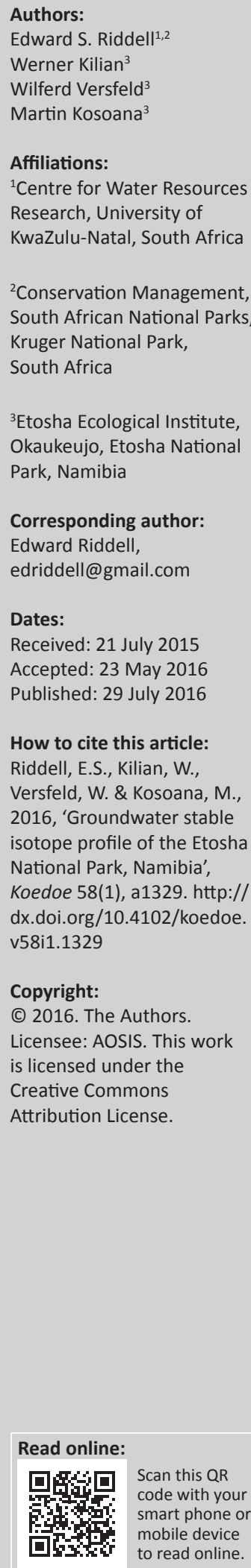

The Etosha National Park (ENP) is a large protected area in northern Namibia. While the ENP has received a lot of research attention in terms of terrestrial ecosystem process understanding in recent decades, aquatic and hydrological research has to date been limited to a descriptive form. This study provides a baseline hydrological data set of the spatial representation of Oand $\mathrm{H}$-isotope ratios in the groundwater at a park scale, with a focus on three water point types utilised by game, namely natural artesian and contact springs as well as artificial boreholes. The data are used to infer broad-scale hydrological process from groundwater recharge mechanisms dominated by direct rainfall recharge in the west of the ENP to evaporative controls on surface water recharge pathways in the east of the ENP close to Fishers Pan. The findings are used to recommend further targeted research and monitoring to aid management of water resources in the ENP.

Conservation implications: The terrestrial ecosystem, particularly large game, are tightly coupled to the distribution of available surface water in the ENP, notably contact and artesian springs. Within the ENP there is a perceived desiccation of these springs. This study provides a baseline upon which more comprehensive studies should be undertaken to differentiate natural from anthropogenic causes for this phenomenon.

\section{Introduction}

The requisite holistic understanding of natural and social environments within and around protected areas includes determining the complexities and challenges of managing water in their terrestrial environment (González et al. 2013). These challenges include increasing water demands and often altered catchment processes arising from increasingly dense and urbanising populations on the peripheries of small and large protected areas, as seen frequently in Southern Africa. The Etosha National Park (ENP) in north-central Namibia is a case in point. The ENP encompasses a biologically diverse semi-arid woodland savanna ecosystem, whose core is occupied by a large depression, the Etosha Pan. This is a superpan formed during the Pleistocene by the coalescing of several smaller pans following the tectonic separation of the Owambo basin from the Kunene basin and consequent deflection of the Kunene river towards the coast during the late Pliocene (Hipondoka 2005; Miller, Pickford \& Senut 2010). The Etosha Pan is also a Ramsar wetland of international importance. In the definition of Rodríguez-Iturbe and Porporato (2004), the ENP would be classified as a water-controlled ecosystem, not only because of its water scarcity but also because of its intermittent and sometimes erratic availability. It is for this reason and the fact that the spatio-temporal distribution of biota in ENP is tightly coupled to its water distribution (Auer 1997) that baseline hydrological studies are required to be undertaken within it. Within this context, a snapshot (conducted over the period of 1 week) survey similar to that developed by Grayson et al. (1997) was undertaken for the ENP during the dry winter months to provide a baseline stable isotope hydrology profile of the ENP.

\section{Research method and design}

The hydrochemical sampling of the water points in ENP was conducted between 05 and 11 May 2013 and took the form of both a west-east and a south-north transect (Figure 1). Three types of water points were considered: groundwater boreholes, artesian springs and contact springs. Twenty-five millilitre veterinary polystyrene vials, which were rinsed three times with sample water before collection and filled to the brim to prevent evaporative fractionation, were used in the following manner:

- Groundwater borehole: By collection from borehole taps (ensuring that the pump was running continuously to the water trough in order that an unevaporated sample was collected from the aquifer). 


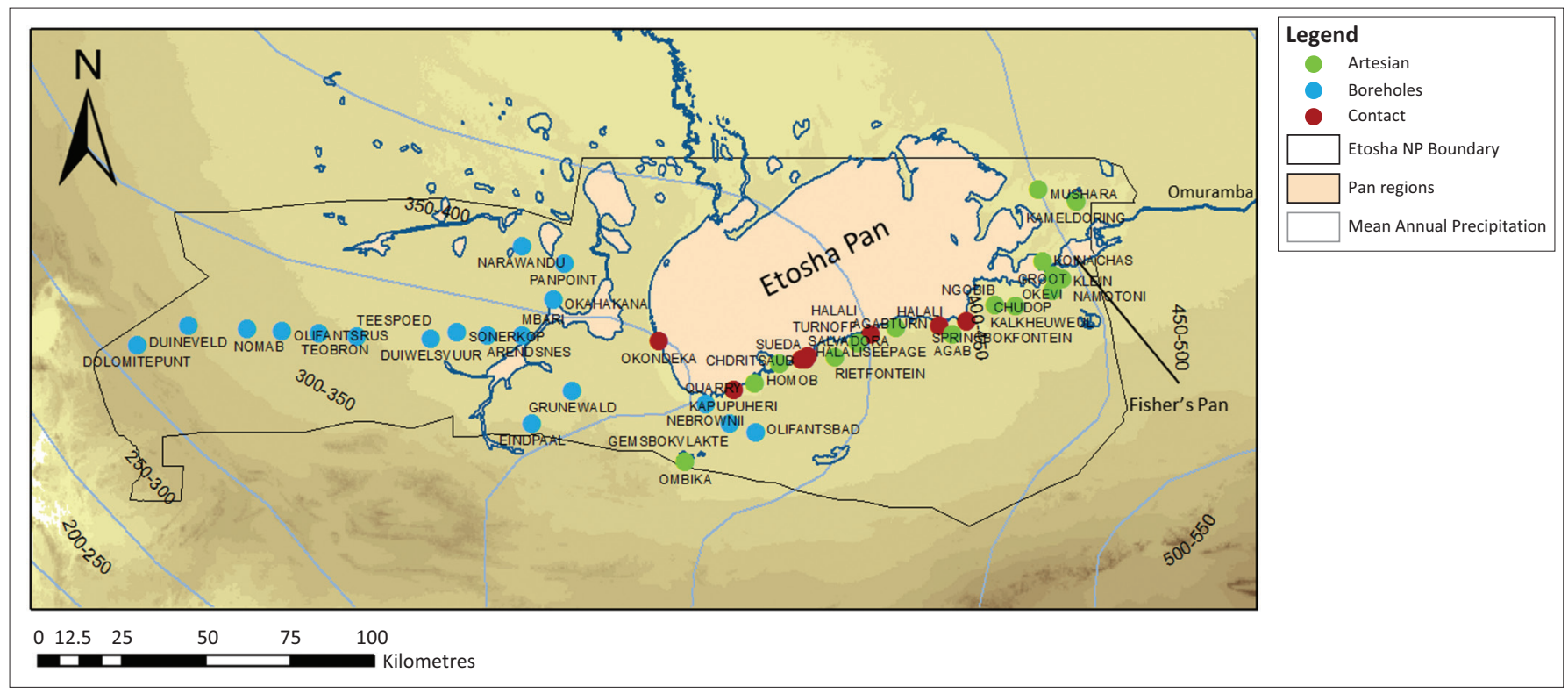

FIGURE 1: Location of groundwater sampling points following an approximate west-east (Dolomietpunt to Kameldoring) and south-north (Eindpal to Mbari) transect in the Etosha National Park, May 2013.

- Artesian springs: A sink-bottle sampler $(500 \mathrm{~mL}$ plastic drinks bottle with weight tied to the bottle opening and three pin holes introduced at the base, so that bottle sinks into the water column) tied to a rope and thrown as close to the artesian spring eye as possible.

- Contact spring: Free flowing water in the contact spring.

Field samples were stored in a cooler bag and then stored in a fridge before transport to the laboratory.

A second sample was taken in the field to determine temperature $\left({ }^{\circ} \mathrm{C}\right) \pm 0.5{ }^{\circ} \mathrm{C}$, electrical conductivity $(\mathrm{mS} / \mathrm{cm}) \pm 1 \%$ full scale and $\mathrm{pH} \pm 0.01 \mathrm{pH}$ using a calibrated EUTECH Instruments PCSTestr 35 pocket tester. Samples were then sent to the University of KwaZulu-Natal to measure the stable isotope compositions of oxygen-18 $\left(\mathrm{O}^{18}\right)$ and deuterium $\left(\mathrm{H}^{2}\right)$ using a Los Gatos Research (LGR) DT-100 Liquid Water Isotope Laser Analyser and analysed six times to provide a high-value precision using in-house standards of Indian Ocean Water $\left(\delta^{2} \mathrm{H}\right.$ $4.75 \%$ $\pm 0.41 \%$; $\delta^{18} \mathrm{O} 0.06 \%$ $\pm 0.30 \%$ ) and Spring Water (Avian Bottled Water $\delta^{2} \mathrm{H}-61.43 \%$. $\pm .56 \% ; \delta^{18} \mathrm{O}-4.05 \%$ $\pm 0.29 \%$ ) and a 50:50 mixture of these. The standards were prepared against International Atomic Energy Agency (IAEA) standards LGR2, VSMOW2 and IA-RO53 during which standard deviations of $\delta^{2} \mathrm{H}$ were less than $2 \%$ and $\delta^{18} \mathrm{O}$ less than $0.3 \%$. At each point, a differential GPS reading was also taken with Trimble GeoExplorer $3^{\circledR}$ to determine accurate elevations above the mean sea level $( \pm 10 \mathrm{~cm})$.

\section{Results and discussion}

Field data may be found in Table 1 and are discussed here in summary form to give an overall picture of the isotope composition of groundwater in the ENP during the short time period of 1 week. This data set may thus be used to augment the spatially representative but temporally disparate data set presented by Auer (1997).
As seen in Figure 2, in all cases the water sampled during May 2013 in the ENP show signs of having been evaporated. Because all samples plot below the Global Meteoric Water Line (GMWL), this gives a generalised local evaporation line (LEL) from these groundwater samples. The LEL with a slope of 5.1 is in similar agreement with the 5.2 LEL slope developed in Lindenmaier and Christelis (2012). The Windhoek meteoric water line is plotted for reference, because this is the closest available long-term data set for the region. While this has a slope of 7.13, Gaj et al. (2016) produced a Local Meteoric Water Line for the Cuvelai-Etosha basin to the north with a slope of 7.3. The plotting of all groundwater stable isotope data below the GMWL would be expected given the high potential evapotranspiration (2600 mm - $2800 \mathrm{~mm}$ per annum) for the region and the convective nature of rainfall in northern Namibia, whose origins are in the Zaire Air Boundary of the Inter-Tropical Convergence Zone (see Engert 1997). Overall, there is a clustering of borehole, contact spring and artesian spring water (central), but several contact and artesian spring waters show evaporative loss (plotting to the right and below the GMWL). These data are plotted in Figures 3 and 4 with spatial and altitudinal distribution and as a function of the deuterium excess, or d-excess $\left(\delta^{2} \mathrm{H}-8^{*} \delta^{18} \mathrm{O}\right)$. Where the lower the numeric value, the influence of evaporation becomes more likely as $\delta^{18} \mathrm{O}$ increases, as result of the different equilibrium fractionation between the water molecules of ${ }^{2} \mathrm{H}^{1} \mathrm{H}^{16} \mathrm{O}$ as related to ${ }^{1} \mathrm{H}^{1} \mathrm{H}^{18} \mathrm{O}$ (Dansgaard 1964).

Figure 3 shows that most of the sampled water points in ENP plot between $-5 \%$ and $5 \%$ for d-excess while several artesian water points (Homob, Ngobib, Chudop, Klein Namutoni, Koinahas and Groot Okevi) have d-excess lower than -5\%. In general terms then, it can be speculated that the artesian water points suggest more variability in their water origins. The fact that this variability is pronounced in the east of ENP 
points to the role of the Oshivelo artesian and phreatic aquifers as being the primary groundwater pathways in this region as described by Christelis and Struckmeier (2011). Meanwhile, Mushara and Kameldoring plot in a very similar range $\left(<-6 \%\right.$ for $\delta^{18} \mathrm{O}$ and $<-50 \%$ for $\left.\delta^{2} \mathrm{H}\right)$ as groundwater samples reported from 2008 in the north-east corner of the Etosha Pan by Lindenmaier and Christelis (2012).

The boreholes in the west of ENP all show relatively low delta values compared with the entire range of samples. It was noted by Department of Water Affairs and Forestry (2006) that the borehole at Dolomietpunt showed a relatively large and rapid response to significant rains during the 2005 rainy season and that soils in the west are typically sandy (Beugler-Bell \& Buch 1997). The boreholes that align in an approximate south-north

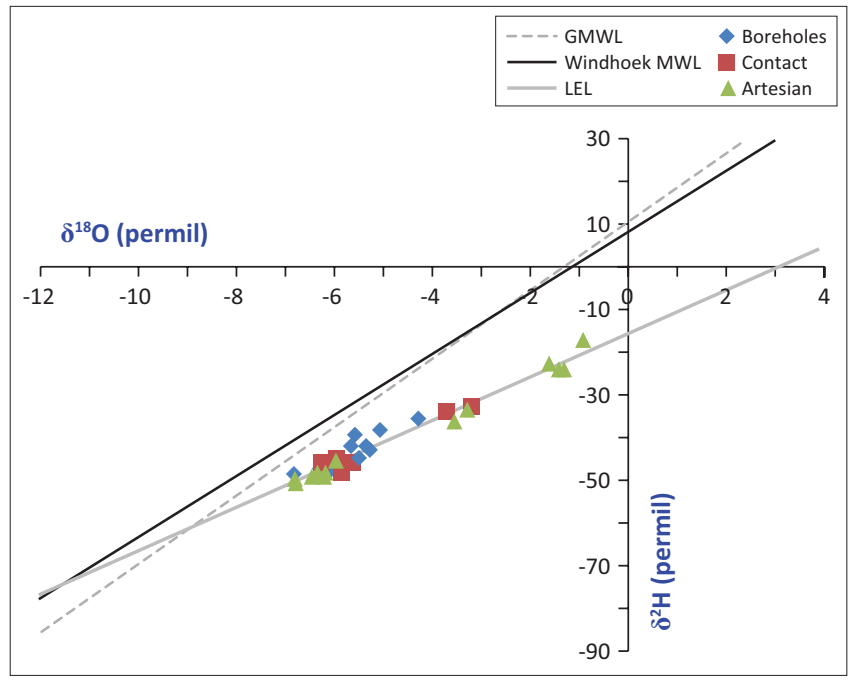

FIGURE 2: Stable isotope results $\left(\delta^{18} \mathrm{O} / \delta^{2} \mathrm{H}\right)$ for samples of different water point types in the Etosha National Park, May 2013 (Windhoek Meteorological Water Line developed from International Atomic Energy Agency Global Network of Isotopes in Precipitation database 1961-2001). orientation to the west of the Etosha Pan (Figure 4) also show low delta values, similar to those further west (as in Figure 3). Hence, these depleted groundwaters in the west of ENP may then be indicative of direct recharge from large rain events through hydraulically conductive Kalahari sands in an otherwise low rainfall region ( $300 \mathrm{~mm}$ pa $-350 \mathrm{~mm}$ pa). This will cause a minor evaporation of the recharging water body as it moves rapidly below the root zone of the evapotranspiring vegetated surface.

In general, the EC readings (Figure 5) reveal the same trends described by Auer (1997) in that the western region of ENP has low EC values. In this case, $<250 \mathrm{mS} / \mathrm{m}$, which is in line with Auer's (1997) alkaline earth-hydrogen carbonate water, which is low in ions in the extreme west of ENP, which up to Toespad is $<300 \mathrm{mS} / \mathrm{m}$. This freshwater chemistry is similar to Auer's (1997) data in the south of ENP at Ombika and also Gruneveld and Panpoint. We found high EC at $>500 \mathrm{mS} / \mathrm{m}$ at Eindpal and Narawandu, and this is similar to that found

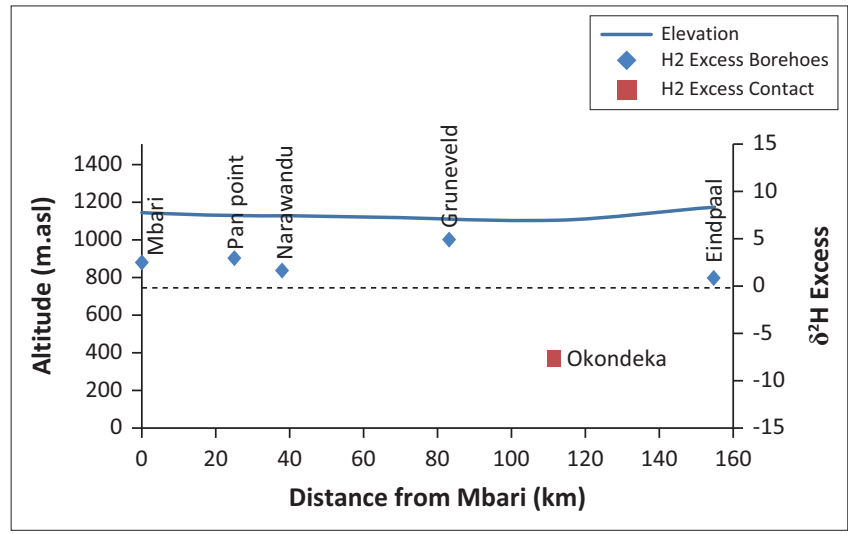

FIGURE 4: Variation of altitude, $\delta^{2} \mathrm{H}$ and $\delta^{18} \mathrm{O}$ (above) and $\delta^{2} \mathrm{H}$ excess (below), along an approximate north-south transect for different water point types in the Etosha National Park, May 2013, with altitude reference.

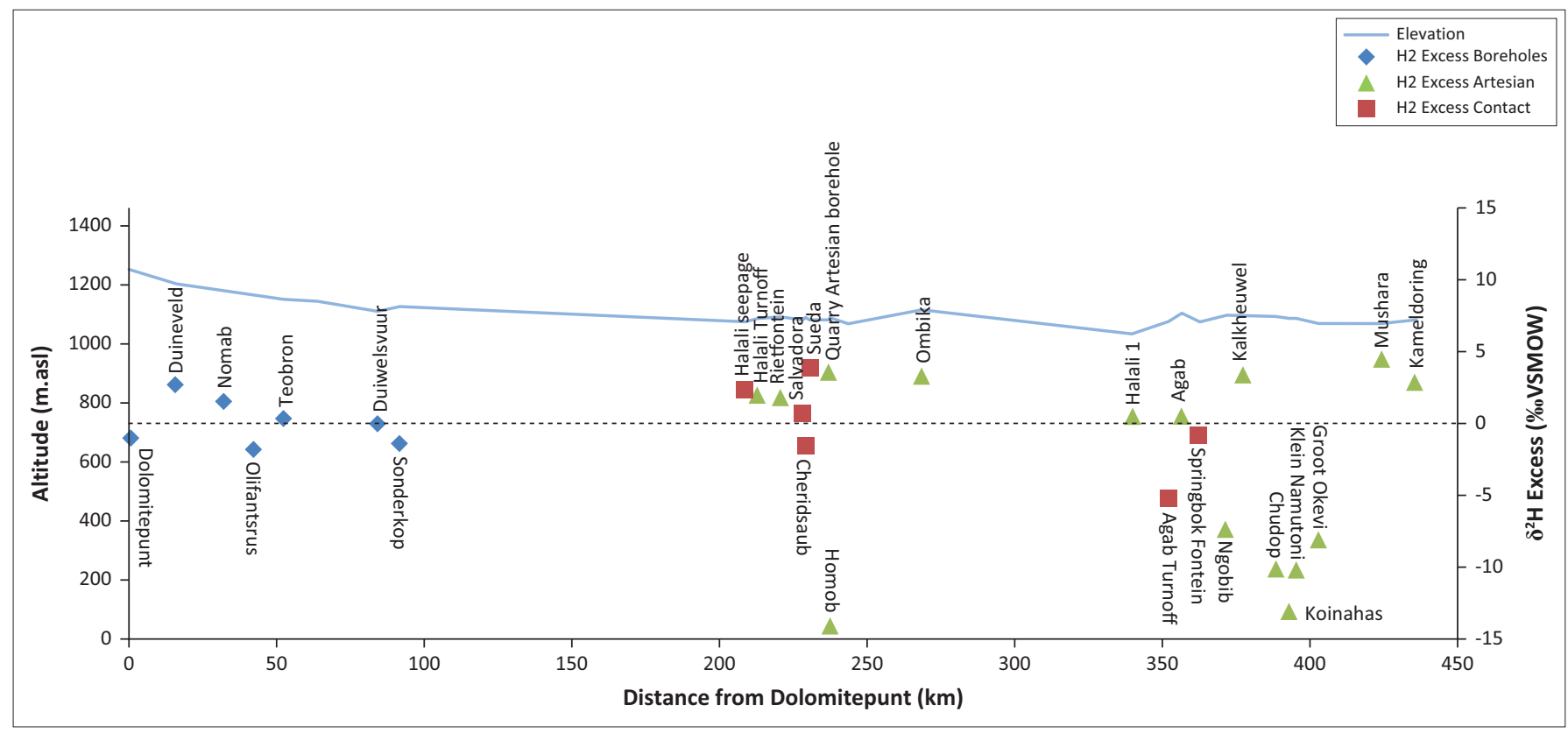

FIGURE 3: Variation of altitude, $\delta^{2} \mathrm{H}$ and $\delta^{18} \mathrm{O}$ (above) and $\delta^{2} \mathrm{H}$ excess (below) along an approximate east-west transect for different water point types in the Etosha National Park, May 2013, with altitude reference. 
by Auer (1997); however, they showed that EC was greater in the case of the former, whereas we found the opposite. Meanwhile, we found Mbari to have a low EC, which appeared to have not been sampled by Auer (1997). In the east of ENP, water sampled in this study at both contact and artesian springs along the shore of the pan generally had EC $>300 \mathrm{mS} / \mathrm{m}$. This is generally in agreement with Auer's (1997) data, although there are some spatial inconsistencies between the two data sets, at specific points. Although not revealed in our sampling, in the Auer (1997) data there is an increase in EC closer to the shore of the pan.

The spatial distribution of temperature $\left({ }^{\circ} \mathrm{C}\right)$ in ENP is shown in Figure 6. Typically, there is a general decrease in groundwater temperature at the boreholes west of Deiwelsvuur, which augments the theory of more direct recharge through the Kalahari sands and local dolomite formations by incoming rainfall as one moves further west. In the east of ENP, around the shores of the pan, temperature is more variable and indicative therefore of the various source pathways of water from the Oshivelo aquifer system emerging at artesian discharge or contact points. Of interest are the contact springs Halali and Sueda, which both have cool temperatures $\left(19.4^{\circ} \mathrm{C}\right.$ and $20.3^{\circ} \mathrm{C}$, respectively) and very high EC $(10.58 \mathrm{mS} / \mathrm{m}$ and $9.72 \mathrm{mS} / \mathrm{m})$ indicative perhaps of deep water sources traversing through weathered limestone in that region. In the far east of the pan, around Fisher's Pan, the temperature is also reasonably low $\left(23^{\circ} \mathrm{C}-24^{\circ} \mathrm{C}\right)$ while the waters show some evaporative loss as suggested by the very low d-excess values. This suggests direct shallow recharge by water flowing into Fisher's Pan from the Omuramba-Owambo river but where it is subject to significant evaporation in and around the pan before replenishing groundwater in the area.

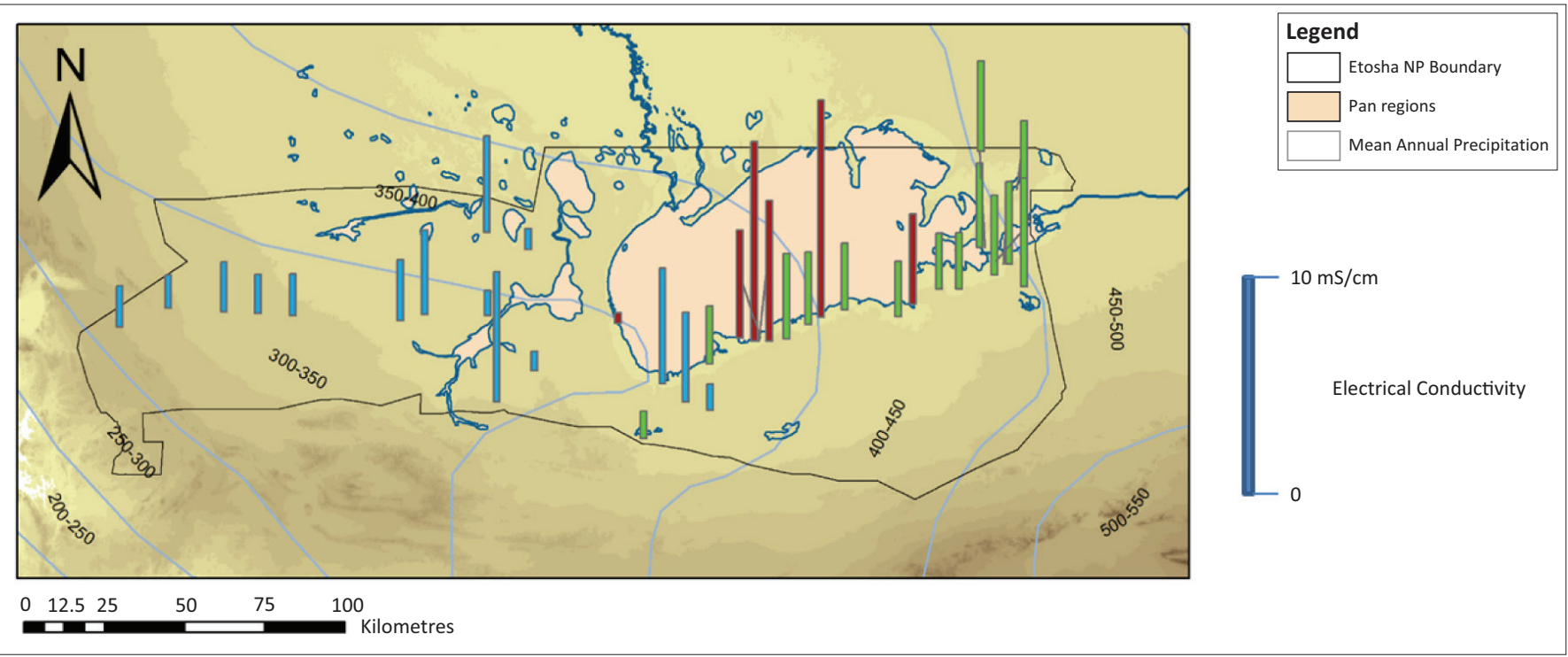

FIGURE 5: Spatial distribution of EC (mS/cm) for different water point types in the Etosha National Park, May 2013. (Possible instrument error as uncalibrated spare multiparameter meter had to be used for all the south-north transect points, 10 May 2013.)

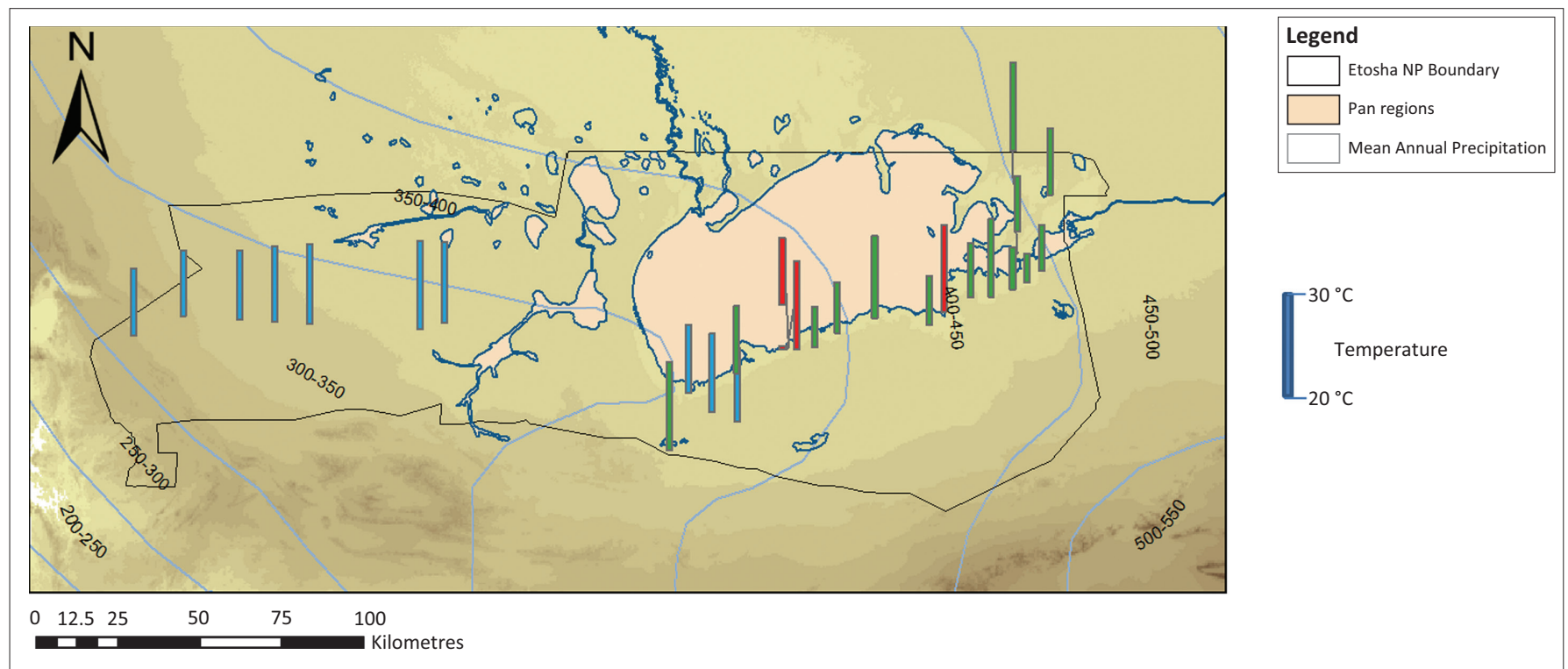

FIGURE 6: Spatial distribution of temperature for different water point types in the Etosha National Park, May 2013. 
The distinction in water point types that arises from the temperature data is reaffirmed in Figure 7, which displays a ternary plot of d-excess, EC and temperature, which along with $k$-means analysis (Table 2) depict three distinct clusters to the water samples. Cluster 1 represents the majority of the water samples and includes those from all three water source types throughout the ENP. It is also important to note within cluster 1 the close clustering of borehole water samples, suggesting very similar hydrochemistry, at least under this limited analysis. Meanwhile, cluster 2 represents only artesian boreholes. All are at the far east of the ENP with the exception of Homob. Cluster 3 consists of only two contact springs on the southern shores of the Etosha Pan at Sueda and Halali.

Based on this snapshot analysis of groundwater in the ENP, a preliminary picture is inferred from the data to broadly distinguish two hydrogeological areas: the west of the ENP is likely to have groundwater that is recharged relatively directly from incoming rainfall through the sandy substrate in that landscape and from the dolomite ridge that runs along the south-western boundary of the park; meanwhile, the east is much more complex, as revealed by the $k$-means analysis, which clusters artesian and contact springs into three water facies. The network of artesian and contact springs that are likely to be connected to the Oshivelo aquifer arise from the

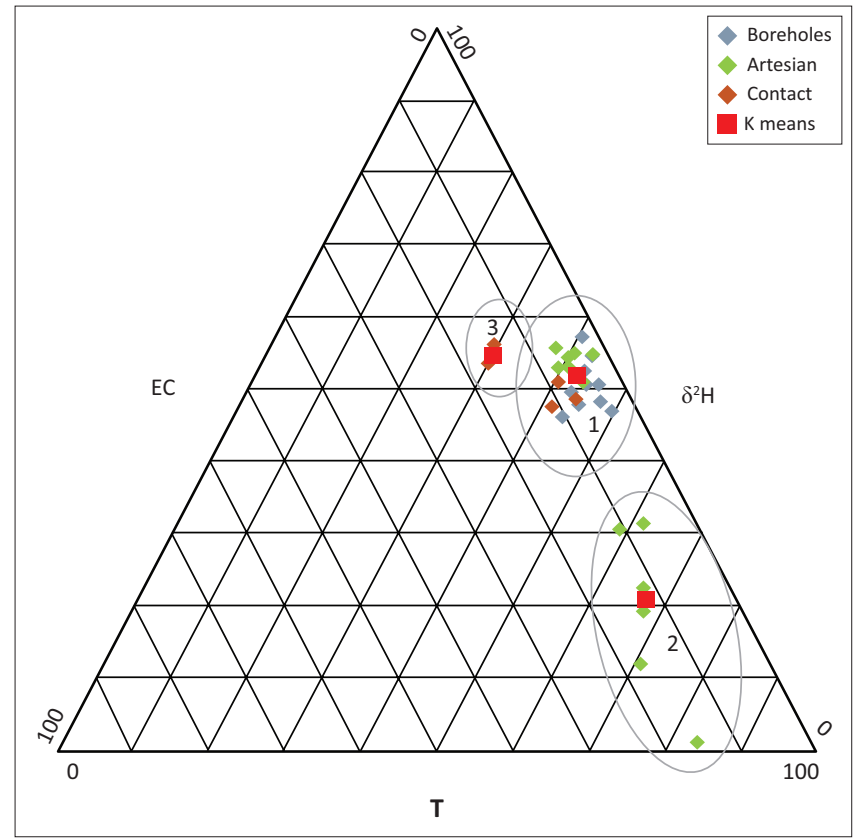

FIGURE 7: Ternary plot with normalised data (percentiles) for EC $(\mathrm{mS} / \mathrm{cm})$ temperature $\left({ }^{\circ} \mathrm{C}\right)$, and $\delta^{2} \mathrm{H}$ excess for different water point types in the Etosha National Park, May 2013, inclusive of $k$-means centroids (north-south transect samples omitted from the analysis because of unreliable multi-parameter probe readings).

TABLE 2: $k$-means centroids for groundwater $\mathrm{EC}(\mathrm{mS} / \mathrm{cm})$, temperature $\left({ }^{\circ} \mathrm{C}\right)$, and $\delta^{2} \mathrm{H}$ excess recorded in the Etosha National Park during May 2013.

\begin{tabular}{lcccc}
\hline Class & $\boldsymbol{\delta}^{2} \mathbf{H}$ excess & $\mathrm{EC}(\mathrm{mS} / \mathrm{cm})$ & Temp ${ }^{\circ} \mathrm{C}$ & $\boldsymbol{n}$ \\
\hline 1 & 1.08 & 3.61 & 26.6 & 22 \\
2 & -10.71 & 4.52 & 24.6 & 6 \\
3 & 2.99 & 10.15 & 19.9 & 2 \\
\hline
\end{tabular}

Tsumeb-Grootfontein dolomite complex. The data here support the conceptual model of a stratified Oshivelo aquifer system as described by Christelis and Struckmeier (2011).

\section{Recommendations for management}

There are a number of questions and recommendations raised by this limited study that could be used to inform future water availability and management strategies in the ENP. First and more locally would be to determine the hydrological processes maintaining the Okondeka freshwater spring, which makes it geographically distinct from other springs in the region, because it is the only active contact spring on the western shores of the Etosha Pan. The possibility that the dune fields to the west supply local recent event rainfall freshwater could be explored, as this would warrant that spring system a unique ecosystem type within the ENP. The second broader, pertinent issue is to develop a groundwater hydrodynamic and hydrochemical monitoring programme for the ENP and its groundwater catchments. The purpose of this will be to further characterise the hydrogeological processes in different water regions of the park, for example, western region and eastern region. For instance, feedback from managers in the ENP suggests that there has been a steady desiccation of the springs along the south-west of the pan. It will need to be determined whether this is as a result of inter-glacial climate cycling or something more serious, such as groundwater over-abstraction elsewhere in the catchment and/or enhanced precipitation interception and transpiration from bush thickening in the karst aquifer of the region (e.g. Namibia Agriculture Union 2010).

\section{Conclusion}

The results of this snapshot hydrochemical and stable isotope characterisation of groundwater in the ENP have revealed a close clustering of borehole water properties towards the west of the park and the d-excess values there suggest direct recharge by rainfall through the Kalahari sands. The west of the park clearly has a more complicated groundwater flow pathway and the variable hydrochemistry reported here for artesian and contacts springs along the southern shore of the Etosha Pan support the conceptualised flow paths of other studies. The results of this baseline study could be used in future long-term hydrological change monitoring of the Etosha ecosystem, especially with respect to understanding the causes for apparent desiccation of contact springs along the southern shores of the pan.

\section{Acknowledgements}

Dr Jaco Nel of Groundwater Consulting Services is acknowledged for his advice in preparation for the field study and lending of some field equipment. Mr Cobus Pretorius is acknowledged for analysing the water samples for stable isotopes at Soil \& Water Laboratory of the Centre for Water Resources Research at the University of KwaZulu-Natal. 


\section{Competing interests}

The authors declare that they have no financial or personal relationships which may have inappropriately influenced them in writing this article.

\section{Authors' contributions}

E.S.R. led the research design and was responsible for data analysis and compiling the manuscript. W.K., W.V. and M.K. assisted with field data collection and site interpretation.

\section{References}

Auer, C., 1997, 'Chemical quality of water at waterholes in the Etosha National Park', Madoqua 20(1), 121-128.

Beugler-Bell, H. \& Buch, M.W., 1997, 'Soils and soil erosion in the Etosha National Park, northern Namibia', Madoqua 20(1), 91-104.

Christelis, G. \& Struckmeier, W., 2011, Groundwater in Namibia: An explanation to the hydrogeological map, Ministry of Agriculture, Water and Rural Development, Windhoek, Namibia, p. 132

Dansgaard, W., 1964, 'Stable isotopes in precipitation', Tellus 16, 436-468. http:// dx.doi.org/10.1111/j.2153-3490.1964.tb00181.x
Department of Water Affairs and Forestry, 2006, Cuvelai-Etosha Groundwater Investigation, Version 1.1. Bittner Water Consult cc, Windhoek, Namibia, p. 72.

Engert, S., 1997, 'Spatial variability and temporal periodicity of rainfall in the Etosha National Park and surrounding areas in northern Namibia', Madoqua 20(1), 115-120.

Gaj, M., Beyer, M., Koeniger, P., Wanke, H., Hamutoko, J. \& Himmelsbach, T., 2016, 'In situ unsaturated zone water stable isotope $\left({ }^{2} \mathrm{H}\right.$ and $\left.{ }^{18} \mathrm{O}\right)$ measurements in semiarid environments: A soil water balance', Hydrology and Earth System Science 20 715-731. http://dx.doi.org/10.5194/hess-20-715-2016

González, H.F., Porras, J.L.C., Guitérez, I.B. \& LaMoreaux, J.W., 2013, Management of water in protected areas, Springer-Verlag, Berlin Heidelberg, p. 351.

Grayson, R.B., Gippel, C.J., Finlayson, B.L. \& Hart, B.T., 1997, 'Catchment-wide impacts on water quality: The use of "snapshot" sampling during stable low flow', Journal of Hydrology 199(1-2), 121-134. http://dx.doi.org/10.1016/S0022-1694(96)03275-1

Hipondoka, M.H.T., 2005, 'The development and evolution of Etosha Pan, Namibia', $\mathrm{PhD}$ thesis, Universität Würzburg, p. 152.

Lindenmaier, F. \& Christelis, G., 2012, Groundwater for the North of Namibia: Summary report of activities of phase I, exploration of Ohangwena II aquifer and preliminary isotope study, vol. 1a, Ministry of Agriculture, Water and Forestry, Windhoek, Namibia, p. 69.

Miller, R, McG., Pickford, M. \& Senut, B., 2010, 'The geology, palaeontology and evolution of the Etosha Pan, Namibia: Implications for terminal Kalahar deposition' South African Journal of Geology 113, 307-334. http://dx.doi. deposition', South African Jour
org/10.2113/gssajg.113.3.307

Namibia Agriculture Union, 2010, The effect of bush encroachment on groundwater resources in Namibia: A desk top study, Final Report, Colin Christian \& Associates, Environmental Consultants, Windhoek, Namibia, p. 126.

Rodríguez-Iturbe, I. \& Porporato, A., 2004, Ecohydrology of water-controlled ecosystems: Soil moisture and plant dynamics, Cambridge University Press, Cambridge. 